\title{
The Influence of Instagram-Assisted Project Based Learning Model on Critical Thinking Skills
}

\author{
Popy Adekantari
}

The Faculty of Teacher Training and Education, University of Mataram, Mataram, Indonesia

\section{Su'ud}

The Faculty of Teacher Training and Education, University of Mataram, Mataram, Indonesia

\section{Sukardi}

The Faculty of Teacher Training and Education \& Postgraduate, University of Mataram, Mataram, Indonesia Correspondence Author

\section{DOI: https://doi.org/10.36941/jesr-2020-0129}

\section{Abstract}

In today's 21st century, people are demanded to have the ability to communicate and to think critically. In addition, we are also expected to possess leadership qualities. In achieving such competencies, IT-Assisted Project Based Learning (PjBL) model can be used as an alternative. Hence, this study was conducted, aiming at determining whether there is an effect of Instagram-Assisted PjBL model on students' critical thinking skills in sociology subjects. This research was a Quasi-Experimental Study, with Nonrandomized Control Group Pretest-Posttest Design. The research data were obtained using objective tests in the form of multiple choice questions, which have passed validity, reliability, discrimination power, and difficulty level test. The data were analyzed using parametric statistical tests, in the form of comparative analysis and $N$-Gain. The results of the study showed that Instagram-Assisted Project Based Learning model had an impact on students' critical thinking abilities. The results of $\mathrm{N}$-Gain test also showed that the increase in students of experimental class' critical thinking skills is higher than that of the students in control class. This implies that Instagram-Assisted Project Based Learning models can be used as a supplement in strengthening constructivist-oriented learning theories

Keywords: Project Based Learning, Instagram, Critical Thinking Skills

\section{Introduction}

In the 21st century, technological development influences all aspects of life. In the field of education, technology enables students to have the ability to: think critically, think creatively, produce new innovations, solve problems, as well as conduct collaborative work (Chatwattana \& Nilsook, 2017). The ability to think critically is not only needed in dealing with challenges and solving problems in daily 
life, but also in helping students construct knowledge.

One problem found in Indonesia is that the students encounter difficulties in developing their critical thinking skills. These difficulties are indicated by the students' inability to discover problems, verify them, and come up with ideas to solve the problems related to social phenomena in the society (Pusparatri, 2012). This inability of the students implies on the students' attitudes and behaviors, in that their attitudes and behaviors are not in line with absolute truth values, such as good or bad values. The phenomena that arise in Indonesia's society are as follows: students brawl, fight, and develop social conflicts that result in fatalities (Pusparatri, 2012). These phenomena are one impact of students' weak critical thinking abilities for such social phenomena. Thus, a learning model that can develop students' critical thinking skills in learning process, especially through sociology subjects, is needed.

The problem in Indonesia is that teachers are still a center and the one playing the dominant role in learning process (Yuliani \& Lengkanawati, 2017). During learning activities, the teacher delivers material to students without involving the students actively. This affects the students' response to the subject, in that they perceive sociology as boring, as having lack of innovation, and as a subject in which the teachers talk and lecture, etc. This is because the teacher is still bound to use traditional methods, such as the lecture method which refers only to the text book used (Effendi, 2012). A lesson that uses traditional teaching approaches results in the students merely receiving the knowledge passively.

Thus, a learning model that can foster students' critical thinking skills based on the principles of constructivism is needed, so that students can participate in the learning activities actively and be given a direct experience (Sadrina \& Mustapha: 2017). One learning model that can create direct experience is Project Based Learning ( $\mathrm{PjBL}$ ) model. PjBL is a learning method that let the students be actively involved, so that it is possible for them to participate during the learning process (Marklund et al., 2014; Lee \& Lim, 2012), either independently or in groups based on their competencies, skills, and interests. Meanwhile, here the teacher only serves as a facilitator who provides guidance and advice (Chatwattana \& Nilsook, 2017). PjBL helps students solve problems (Chatwattana \& Nilsook, 2017; Chu et al., 2012; Robinson, 2013), improve their critical thinking skills (Lee \& Lim, 2012; Hasan et al., 2017), train their decision making skills (Marklund et al., 2014; Thomas, 200o) and can also increase their learning motivation (Sadrina \& Mustapha: 2017).

However, the PjBL model also has some drawbacks, namely: it is costly (Jacques \& Martin, 2016) and it requires a long time to plan (Thomas, 2000; Yu et al., 2016). Therefore, several studies combined it with an application, such as Edmodo (Hursen, 2018), while others use social media such as Instagram (Utami et al., 2015). Combining PjBL model with Instagram is proven to be effective in enhancing students' creative thinking skills in Biology subjects in Indonesia (Utami et al., 2015).

In this study, Instagram serves as a teaching media that utilizes technological developments. Here, Instagram is expected to be able to improve critical thinking skills. It is chosen as a media because it is viewed as a media that keeps track of the current trend and also the media with the highest number of followers among teenagers in Indonesia (Supratman, 2018). Apart from serving as a mean to cover the weaknesses of the PjBL model, Instagram can also be used to facilitate teachers in monitoring the students' activities outside of the classroom. Therefore, this study was conducted with the aim to determine whether Instagram-Assisted PjBL model has any impact on students' critical thinking skills.

\section{Literature Review}

The development of the increasingly complex world causes humans to continue thinking critically. Critical thinking skills are measured, vivid abilities used in mental activities such as making decisions, analyzing assumptions, and solving problems systematically (Jhonson, 2007). Critical thinking is cognitive abilities in the process of logical analysis and argument evaluation (Facione, 200o). This critical thinking was introduced by John Dewey as reflective thinking (Ennis, 2013), and thus some researchers refer to this concept (Choy, \& Cheah, 2009; Rudd, 2007). Critical thinking ability has six basic elements, namely: focus, reason, situation, clarity, and overview (Ratnaningsih, 2017). Critical thinking always begins with asking questions, defining terms, assessing facts, analyzing assumptions, 
considering alternatives in interpreting, and having the ability to engage in reflective and independent thinking, as well as developing a shared understanding of logical relationships between ideas (Singh, 2017). Critical thinking requires efforts and practice so that it can help determine empirical solutions to various problems that someone is facing (Johnson, 2007).

Strengthening students' critical thinking skills requires a learning model that allows learners to manipulate their cognitive skills (Nurbekova et al., 2020). One learning model that can be used to foster a critical mindset in finding and solving problems is the use of Project Based Learning model (Lee \& Lim, 2012; Hasan et al., 2017). PjBL model is a learning model that is based on constructivist principles, which involves students and liberates them to think and develop their thinking skills (Hasan et al., 2017). In order for this model to be more effective, it is combined with social media Instagram which serves as a tool to monitor students outside the classroom so that they are punctual. In addition, it also encourages student learning motivation (Jacques \& Martin, 2016). Many studies have proven the effectiveness of application-assisted project-based approaches in developing soft skills such as critical thinking and communication skills (Muyan-Özçelik, 2017; Rahman, 2018). Media applications are successfully used as a part of innovative educational technology to enhance learning in various disciplines (Dothang Truong, 2014) and mobile application learning is still relevant up to this day (Francese et al., 2015; Scharff \& Verma, 2010). The application of instructional media is also a determining part in the formation of the graduates' competitiveness, viewed from the learning input factors as stated in the Diamond Porter theory (Sukardi et al., 2019).

\section{Method}

The approach used in this study was a quantitative approach, a type of Quasi Experimental with a Nonrandomized pretest-posttest control group (Ary et al., 2010) This is visualized in Figure 1 below.

\begin{tabular}{cccc}
\hline Class (Group) & Pretest & Treatment & Posttest \\
\hline $\mathrm{A}$ & $\mathrm{Y}_{1}$ & $\mathrm{X}$ & $\mathrm{Y}_{2}$ \\
\hline $\mathrm{B}$ & $\mathrm{Y}_{1}$ & - & $\mathrm{Y}_{2}$ \\
\hline
\end{tabular}

Fig. 1. Control Group, Pretest-Posttest Design

As shown in figure 1 , Class A is the Experimental Class which was given Instagram-assisted PjBL model as treatment, while Class B is the control class treated with conventional models. Both classes were given $Y_{1}$ as the pretest and $Y_{2}$ as the final test (Posttest) in order to observe any improvement on critical thinking skills in each class.

The research samples consist of two classes at Senior High School 1 Mataram, one class as experimental class, and one class as control class. Both classes are taken by random sampling after leveling the classes (Ary et al., 2010). Leveling the intended class includes: same teacher, same learning material, same learning time, same number of students, same media and learning facilities, same critical thinking instruments, and same level of learning achievement.

The research data were taken using objective tests in the form of multiple choice questions, which have met validity, reliability, discrimination power, and difficulty level test. In order to obtain instruments of a good quality, in this study, the instruments were put through a trial in the following steps: (1) composing question criteria or outline; (2) writing the questions; (3) reviewing and revising; (3) conducting test practice; (4) conducting trials; (5) analyzing the questions; (6) selecting the questions; (7) making question bank. One example of question items for critical thinking skill is shown in Figure 2 below. 


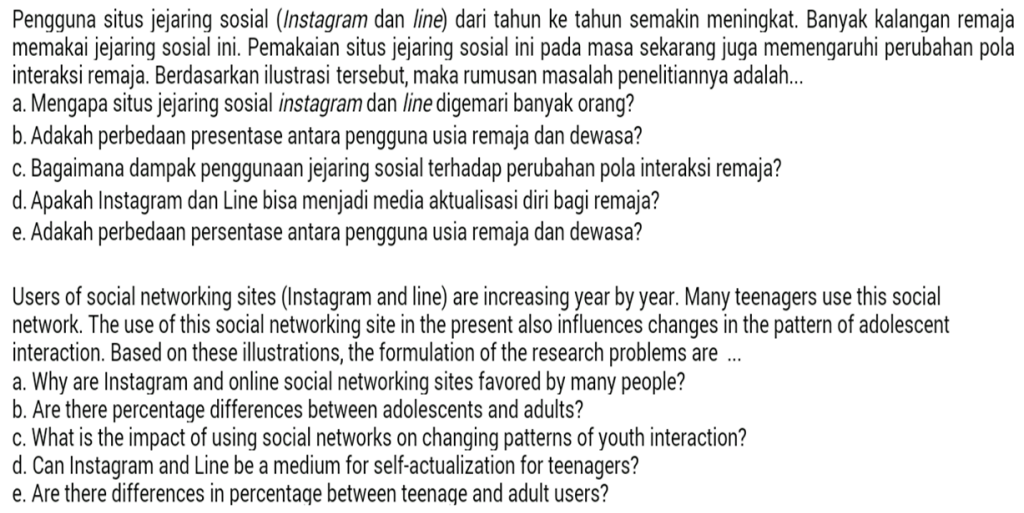

Fig. 2. An example of questions for Students' Critical Thinking Skills

The data obtained were based on the results of the study. The data were then analyzed using comparative analysis procedure with two independent samples after they have passed homogeneity and normality test. In addition to the comparative test, N-Gain test was also carried out. The N-Gain test was used to see the increase on students' critical thinking skills before and after treatment.

\section{Results and Discussion}

Descriptions regarding the results of the study are divided into four parts, namely: instrument test results, analysis requirement test result, hypothesis testing result, and N-Gain test result.

\subsection{Instrument Test Results}

The Instrument Test includes validity, reliability, difficulty level, and discrimination power tests. The results for validity test showed that out of 40 questions, 33 questions were declared valid. The result for reliability test showed that the question criterion is 'high', with a correlation coefficient of 0.85 . The results for difficulty level test discovered that 7 questions were difficult, 14 were moderate, and 12 were easy. Furthermore, the results for discrimination power test for the instruments showed that 8 question items are categorized as 'poor', 8 as 'fair', 11 as 'good', and 6 as 'excellent'. Thus, from the results of the trial and analysis, 30 question items that met the intended instrument quality were obtained.

\subsection{Analysis Requirements Test Result}

The analysis requirements tests for this study include normality and homogeneity test. For normality test using Kolmogorov Smirnov analysis, the Experimental class obtained a value of 0.642 with a probability of $0.804>0.05$, while the control class obtained a value of 1.168 with a probability of 0.130 $>0.05$. Based on these results, it can be concluded that the data for both classes were normally distributed. Furthermore, for homogeneity test using test of homogeneity of variance, the analysis obtain a statistical levene value of 1.161 with a probability value of $0.209>0.05$. Based on these results, it was concluded that the two classes were homogeneous.

\subsection{The Result of Hypothesis Testing}

The calculations results for hypothesis testing are summarized on table 1 below. 
Tabel 1. t-Test Result Summary for Students' Critical Thinking Skills

\begin{tabular}{llcccccc}
\hline Variable & Class/Group & $\mathrm{N}$ & Average $^{2}$ & Sd. & T Score & Df & Sig. \\
\hline \multirow{2}{*}{ Critical Thinking Skills } & Experimental & 36 & 80.33 & 7.946 & \multirow{2}{*}{3.599} & \multirow{2}{*}{70} & \multirow{2}{*}{0.001} \\
\cline { 2 - 5 } & Control & 36 & 72.83 & 9.655 & \multirow{2}{*}{3.59} & \\
\hline
\end{tabular}

Based on the table above, it can be concluded that there is indeed an influence of Instagram-Assisted Project Based Learning models on students' critical thinking skills in Sociology subjects. This is proven by the probability value that scores below 0.05 and the fact that the average value of the experimental class is higher than that of the control class.

\subsection{The Result of N-Gain Test}

To calculate how much the students' critical thinking skills improve, N-gain test was conducted. The results of the $\mathrm{N}$-gain test for both classes are shown in figure 3 below.

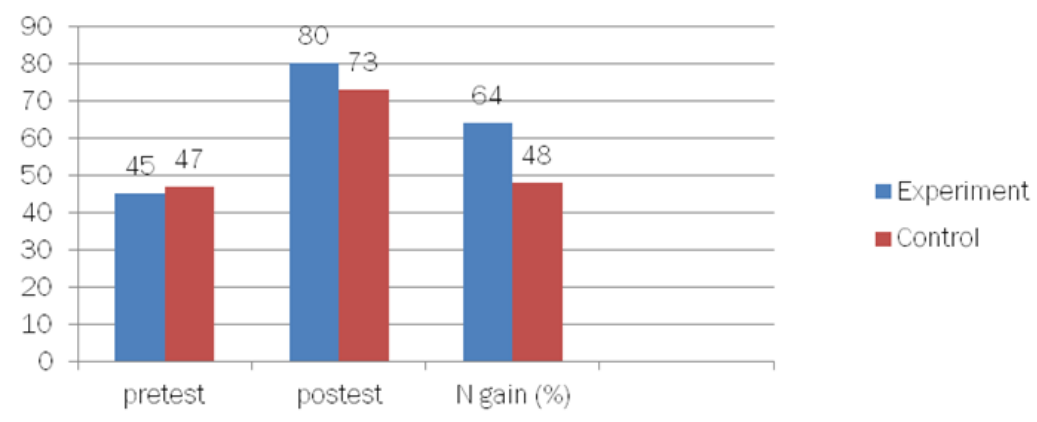

Fig. 3. The Result of N-Gain Test for Experimental Class and Control Class

Furthermore, Figure 4 visualizes differences in the improvement of students' critical thinking skills based on several indicators which include: focus, reason, inference, situation, clarity and overview (Ratnaningsih, 2017).

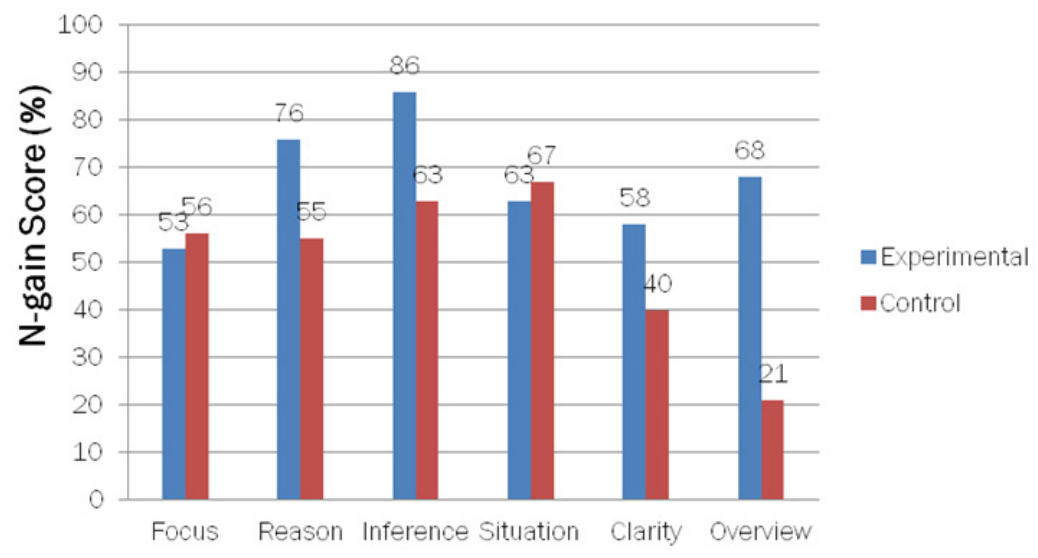

Fig. 4. A comparison of Students' Critical Thinking Skill Improvement for Each Indicator 
As viewed in figure 4, critical thinking skills of students in experimental class are higher than those of students in control class (Figure 4). For example, the experimental class' overview indicator is higher than the control class'. That is because in PjBL, the students were provided with the actual experience in the form of project assignments. Thus, students are able to solve the problems they are facing based on relevant sources.

The implementation of Instagram-Assisted PjBL model received positive responses from students. This can be seen when the students posted their project results on their Instagram account (Figure 5).
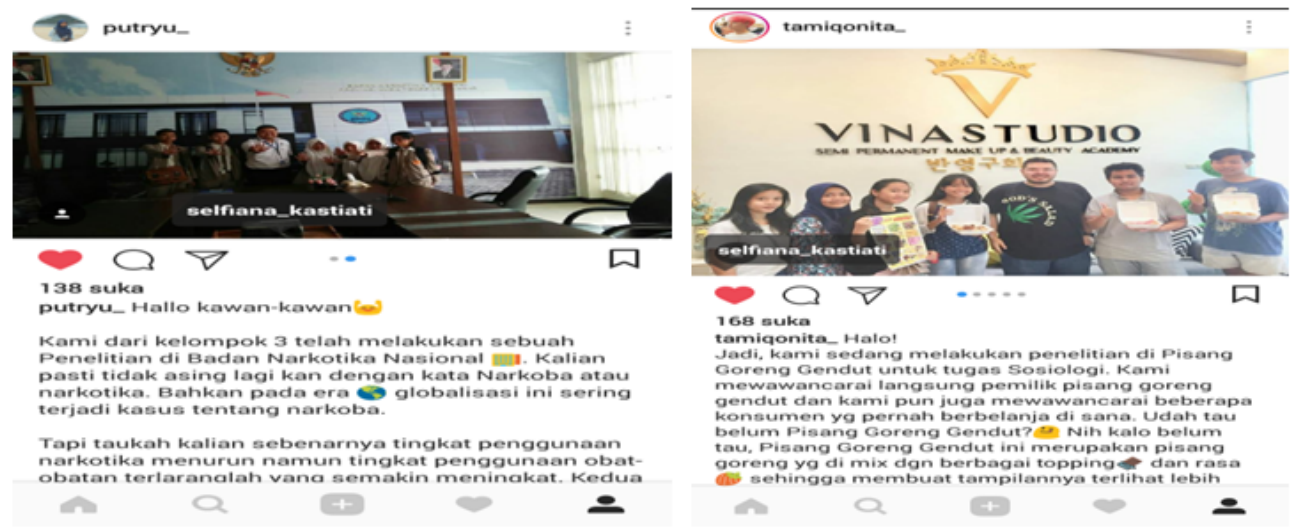

Fig. 5. Screenshot of one of the groups uploading their project to Instagram

Figure 5 shows the students' positive response for lessons that implement PjBL. Through PjBL, students are able to come up with their own ideas through field observation activities, interviews with resource person, seeking information through mass media, etc.

The results above thus prove that a lesson or learning that is based on constructivism theory is still relevant in the 21st century. Constructivism theory creates understanding based on the knowledge obtained from the actual environment and students' experience (Jin, 2017) so that learning becomes more meaningful (Iskander, 2014). The learning process generated in constructivism theory is not only manifested in the form of joint activities, interactions, and cooperation in building knowledge based on reality or social problems, but also through direct practice in the life of the student itself (Sukardi, 2017; Sukardi, 2016).

PjBL provides opportunities for students to make decisions on determining their own projects. The students can develop their critical and creative thinking skills because the two skills are very important in finishing the project (Sadrina \& Mustapha, 2017). PjBL encourages students to have a high level of self-efficacy and perceived control, to be open to group work and mindset growth as well as to have a great potential for deep learning, because they can scaffold real-world knowledge, they gained from developing their project (Iwamoto et al., 2016). The results of the study proved that the implementation of $\mathrm{PjBL}$ has positive impact on the development of students' proficiency in English as a Foreign Language (EFL) in the field of engineering research (Kovalyova, et al., 2016).

The use of technology in the form of Instagram becomes a solution in maximizing the use of time without having to meet face to face. Instagram provides a variety of facilities that can be used as teaching medias, such as: snapgrams photo edits (captions, filters, unique effects and funny stickers), instastories, short videos, boomerang, superzoom, rewind, handsfree and slow motion, and latest update (Supratman, 2018). The results of this study proved that the Instagram-assisted PjBL model was effective in improving students' critical thinking skills. Other empirical evidence also proved that the 
use of Edmodo-assisted PjBL model was effective in improving future teachers' inquiry skills and academic achievements (Hursen, 2018). Students also gave a positive response to the use of Instagram, especially for writing assignments. The participants viewed Instagram as a meaningful learning media in motivating them to write better (Anggraeni, 2017). Thus, this study has confirmed that Instagramassisted PjBL model is one innovative way of learning to improve students' critical thinking skills.

\section{Conclusion}

Based on the results of the research above, it is concluded that Instagram-assisted PjBL model does have an influence on students' critical thinking skills in Sociology subjects. This implies that Instagram Assisted PjBL model can make the lesson more contextual, interesting, and innovative which is student centered so that it fosters the students' motivation and improves their problem solving skills as well as their critical thinking skills. Hence, Instagram-assisted PjBL model serves as a supplement to strengthen the constructivism theory in improving the quality of learning in the social field.

\section{Acknowledgements}

Deepest gratitude goes to Faculty of Teacher Training and Education, University of Mataram for their support during the conduct of the research, up until the completion of this article.

\section{References}

Anggraeni, C. W. (2017, April). Students Perspectives toward the Use of Instagram in Writing Class. In English Language and Literature International Conference (ELLiC) Proceedings (Vol. 1, pp. 68-74).

Ary, D., Jacobs, L. C., Sorensen, C., \& Razavieh, A. 2010. Introduction to Research in Education. Belmont United State: Wadsworth/Thomson Learning Group.

Chatwattana, P., \& Nilsook, P. (2017). A Web-based learning system using project-based learning and Imagineering. International Journal of Emerging Technologies in Learning (iJET), 12(05), 4-22.

Choy, S. C., \& Cheah, P. K. (2009). Teacher perceptions of critical thinking among students and its influence on higher education. International Journal of teaching and learning in Higher Education, 20(2), 198-206.

Chu, R. H., Minasian, R. A., \& Yi, X. (2012). Inspiring student learning in ICT communications electronics through a new integrated project-based learning approach. International Journal of Electrical Engineering Education, 49(2), 127-135.

Dothang Truong. (2014). How to design a mobile application to enhance teaching and learning?. International Journal of Emerging Technologies in Learning (iJET). Vol 9, No 3. (pp. 4-11). https://doi.org/10.3991/ijet.v9i3.3507

Effendi, U. (2012). Pengaruh Metode Pembelajaran Problem Solving terhadap Hasil Belajar. Jurnal Penelitian Inovasi, $37(1)$.

Ennis, R. (2013). Critical thinking across the curriculum: The Wisdom CTAC Program. Inquiry: Critical thinking across the disciplines, 28(2), 25-45.

Facione, P. A. (200o). The disposition toward critical thinking: Its character, measurement, and relationship to critical thinking skills. Journal of Informal Logic, 20(1), 61-84. https:// doi.org/10.22329/il.v2011.2254

Francese, R., Gravino, C., Risi, M., Scanniello, G., \& Tortora, G. (2015). Using Project- Based-Learning in a mobile application development course - An experience report. Journal of Visual Languages \& Computing, 31, 196205. https://doi.org/10.1016/j.jvlc.2015.10.019

Hasan, S. H., Alghazzawi, D. M., \& Zafar, A. (2017). Integrating Java Coding Into Project Based Learning In MLearning Environment. Malaysian Journal of Computer Science, 30(2), 91-98.

Hursen, C. (2018). The Impact of Edmodo-Assisted Project-Based Learning Applications on the Inquiry Skills and the Academic Achievement of Prospective Teachers. Tem Journal-Technology Education Management Informatics, 7(2), 446-455.

Iskander, G. M. (2014). Developing Scale for Assimilate the Integration between Learning Theories and Elearning. International Journal of Emerging Technologies in Learning (iJET), 9(2), 4-8.

Iwamoto, D. H., Hargis, J., \& Vuong, K. (2016). The effect of project-based learning on student performance: An action research study. International Journal for Scholarship of Technology Enhanced Learning, 1(1), 24-42. 
Jacques, S. Bissey \& A. Martin. (2016). Multidisciplinary Project Based Learning Within a Collaborative Framework A Case Study on Urban Drone Conception. University of Tours, Tours, France: https://doi.org/10.3991/ijet.v11i12.5996

Jin, Z. (2017). A Constructivism-based 3D Scene Display Teaching System for Wushu Teaching. International Journal of Emerging Technologies in Learning (iJET), 12 (o1), 84-94.

Johnson, E. B. 2007. Contextual Teaching dan Learning Menjadikan Kegiatan Belajar-Mengajar Mengasyikkan dan Bermakna. Bandung: MLC.

Kovalyova, Y., Soboleva, A. V., \& Kerimkulov, A. T. (2016). Project based learning in teaching communication skills in English as a foreign language to engineering students.

Lee, H.-J., \& Lim, C. (2012). Peer Evaluation in Blended Team Project Based Learning: What do Students Find Important Find Important? Educational Technology \& Society, 15 (4), 214-224.

Marklund, B. B., Backlund, P., Dahlin, C. J., Engström, H., \& Wilhelmsson, U. (2014). A game-based approach to support social presence and awareness in distributed project-based learning. International Journal of GameBased Learning (IJGBL), 4(1), 1-20.

Muyan-Özçelik, P. (2017). A hands-on cross-platform mobile programming approach to teaching OOP concepts and design patterns. In Proceedings of the 1st International Workshop on Software https://doi.org/10.1109/secm.2017.12

Nurbekova, Z., Grinshkun, V., Aimicheva, G., Nurbekov, B., \& Tuenbaeva, K. (2020). Project-Based Learning Approach for Teaching Mobile Application Development Using Visualization Technology. International Journal of Emerging Technologies in Learning (iJET), 15(08), 130-143.

Pusparatri, R. K. D. (2012). Strategi pembelajaran berbasis masalah untuk meningkatkan kemampuan berpikir kritis siswa. Jurnal Ilmiah Guru Caraka Olah Pikir Edukatif, 16(2).

Rahman, F. (2018). Integrating Project-Based Learning in Mobile Development Course to Enhance Student Learning Experience. In Proceedings of the 19th Annual SIG Conference on Information Technology Education(pp. 1-6). International World Wide Web Conferences Steering Committee.

Ratnaningsih, N. (2017). Membangun Keterampilan Berpikir Kritis Matematik Mahasiswa Melalui Pengembangan Media Pembelajaran Interaktif Pada Teori Group. Jurnal Siliwangi Seri Pendidikan, 2(2).

Robinson, J. K. (2013). Project-based learning: improving student engagement and performance in the laboratory. Analytical and bioanalytical chemistry, 405(1), 7-13.

Rudd, R. D. (2007). Defining critical thinking. Techniques, 82(7), 46-49.

Sadrina, S., \& Mustapha, R. (2017). The Evaluation of Project-Based Learning at the Mechanical Engineering Department, Polytechnic Malaysia: A Prosess Dimension Assessment. CIRCUIT: Jurnal Ilmiah Pendidikan Teknik Elektro, 1(1).

Scharff, C., \& Verma, R. (2010). Scrum to support mobile application development projects in a just-in-time learning context. In Proceedings of the 2010 icse workshop on cooperative and human aspects of software engineering (pp. 25-31). ACM. https://doi.org/10.1145/1833310.1833315

Singh, N.K (2017). Skills of Critical Thinking. International Journal of Emerging Trends in Science and Technology, 4(05), 5180-5182. Retrieved from http://ijetst.in/index.php/ijetst/article/view/1104

Sukardi, S. (2016). Desain Model Prakarya dan Kewirausahaan Berbasis Ekonomi Kreatif Berdimensi Industri Keunggulan Lokal. Jurnal Cakrawala Pendidikan, 35(1).

Sukardi, S. (2017). Efektivitas Model Prakarya dan Kewirausahaan Berbasis Ekonomi Kreatif Berdimensi Industri Keunggulan Lokal terhadap Keinovatifan Siswa. Jurnal Cakrawala Pendidikan, 36(2), 267-279.

Sukardi, S., Rusdiawan, R., \& Wardana, L. (2019). The Competitiveness of Master of Education Graduates: Porter's Diamond Analysis. International Journal of Emerging Technologies in Learning (iJET), 14(19), $179-187$.

Supratman, L. P. (2018). Penggunaan Media Sosial oleh Digital Native. Jurnal Ilmu Komunikasi, 15(1).

Thomas, J. W. (200o). A review of research on project-based learning. The Autodesk Foundation 111 McInnis Parkway San Rafael: California.

Utami, R. P., Probosari, R. M., \&Fatmawati, U. M. I. (2015). Pengaruh Model Pembelajaran Project Based Learning Berbantu Instagram Terhadap Kemampuan Berpikir Kreatif Siswa Kelas X Sma Negeri 8 Surakarta. BioPedagogi, 4(1), 47-52.

Yuliani, Y., \& Lengkanawati, N. S. (2017). Project-based learning in promoting learner autonomy in an EFL classroom. Indonesian Journal of Applied Linguistics, 7(2), 285-293. 